\title{
Tıbbi Mümessillerin İş Tatmini Seviyesinin ve İş Tatminini Etkileyen Faktörlerin Belirlenmesi*
}

\author{
Determination Of The Factors That Affect The Job Satisfaction And Job Satisfaction \\ Level Of The Medical Representatives
}

\author{
Burcu ORALHAN** \\ Çağatay IBBILI $\dot{I}^{* * *}$
}

\begin{abstract}
$\ddot{O} Z$
İs tatmini, firmalar için hayati öneme sahiptir. Firmalarda çalışan personelin iş tatmininin yüksek olmasl, verimlilik artışını, firma sadakatini ve en önemlisi firmanın amaç ve hedeflerini benimseyen personelin devamlılı̆̆ını sağlamaktadır. İs tatminini etkileyen bireysel, örgütsel ve sosyokültürel kriterler bulunmaktadır. İs tatmininin ölçülmesi bu kriterlere bağlldır. Bu çalı̧̧manın temel amacı, Kayseri ilinde görev yapan tıbbi mümessillerinin iş tatmin seviyesinin ölçülmesi, iş tatminini etkileyen kriterlerin belirlenmesi, önceliklendirilmesi ve bu kriterler ile iş tatmini arasindaki iliş̧kinin tespit edilmesidir. İş tatminini etkileyen kriterlerin önceliklendirilmesi için çok kriterli karar verme yöntemlerinden AHP kullanılmıştır. Çalışmada kullanılan Spector ölçeği sonuçlarına göre orta düzey iş tatmini seviyesi görülmüş ve en yüksek tatmin kriterleri işin kendisi, iletiş̧im ve iş arkadaşları olarak karş̧ımıza çıkmıştır. Korelasyon analizine göre belirlenen 8 kriter ile iş tatmini arasında pozitif yönlü ilişsi olduğu görülmüştür. ANOVA'ya göre ise iş tatmini ile gelir grupları ve ek imkanlar arasında istatistiksel olarak farklılık olduğ u görülmüsstür. Tibbi mümessiller için iş tatmini kriterleri sırasıyla iletişim, yönetici, işin kendisi, ücret ve çallşma şartlart önceliklendirilmiştir. İ̧̧ tatmininin ölçülmesiyle, sektörler veya firmalar personelin iş tatmin seviyesini ögrenmekle beraber, ileride yapacakları çalı̧̧malar ve iyileştirmeler için temel teşkil etmiş olacaktır. Bu sayede belirlenen iş tatmin seviyeleri yullar boyu izlenebilecek olup, iş tatmininin iyileştirilmesinde yol gösterici bir araç olarak kullanılabilecektir.
\end{abstract}

\section{ANAHTAR KELIMELER \\ Tıbbi Mümessil, İş Tatmini, Spector Ölçeği, ÇKKV, AHP}

\begin{abstract}
Job satisfaction is vital for the firms. The measurement of job satisfaction is based on those criteria. The main aim of this study is to measure the job satisfaction levels of the medical representatives carrying on a business in Kayseri, to determine and prioritize the criteria affecting job satisfaction, to detect the relationship between those criteria and job satisfaction. AHP, which is one of multi-criteria decision-making methods, was used to prioritize the criteria affecting job satisfaction. According to the Spector scale study results, the mid-level job satisfaction was observed and the highest satisfaction criteria appeared as the job itself, the communication and the co-workers. It was seen that there was a positive-directed relationship between 8 criteria determined based on the correlation analysis and the job satisfaction. According to ANOVA, it was seen that there was a statistical difference between the job satisfaction and the income groups and additional opportunities. The job satisfaction criteria- the communication, the director, the job itself, salary/wage and working conditions- were respectively prioritized. By measuring job satisfaction, the sectors or firms shall learn the job satisfaction levels of the employees, and it shall be the basis of the studies and improvements which the firms shall make in the future.
\end{abstract}

\section{KEYWORDS}

Medical Representative, Job Satisfaction, Spector Scale, MCDM, AHP

\begin{tabular}{|c|c|c|}
\hline \multicolumn{2}{|c|}{$\begin{array}{c}\text { Makale Geliş Tarihi /Submission Date } \\
\text { O6.02.2019 }\end{array}$} & \multicolumn{1}{c|}{$\begin{array}{c}\text { Makale Kabul Tarihi / Date of Acceptance } \\
\text { Atıf }\end{array}$} \\
\hline \multirow{3}{*}{$\begin{array}{l}\text { Oralhan, B., İbili, Ç. (2019). Tibbi Mümessillerin İş Tatmini Seviyesinin ve İş Tatminini Etkileyen Faktörlerin } \\
\text { Belirlenmesi. Selçuk Universitesi Sosyal Bilimler Meslek Yüksekokulu Dergisi, 22 (1),161-174 }\end{array}$} \\
\hline
\end{tabular}

\footnotetext{
* Bu çalışma yüksek lisans tezinden üretilmiştir

** Dr.Öğr.Üyesi, Nuh Naci Yazgan Üniversitesi, İktisadi ve İdari Bilimler Fakültesi Nuh Naci Yazgan Üniversitesi, boralhan@nny.edu.tr, ORCID: 0000-0001-8905-0140

*** Uzman, Acıbadem Hastanesi, cagatayibili@gmail.com, ORCID: 0000-0003-2481-006X
} 


\section{GİRiș}

Örgütlerin hedeflere ulaşılmasında en önemli bir faktör olan iş tatminin sağlanması ve yükseltilmesi için ilk başta iş tatminini sağlayan faktörlerin neler olduğunun bilinmesi ve öğrenilmesi gerekir. İş görenin işe karş1 olan tutumunu belirleyen faktörlerin herhangi birisi tek başına belirleyici olmaz. Çalışan personelin işe karş1 tavrını belirleyen faktörler bireysel faktörler, örgütsel faktörler, sosyo kültürel çevre olarak 3 ana başlık altında toplanabilir (Tuta, 2008: 49).

Çalışanların yaşı, cinsiyeti, kişilik özellikleri, kişisel eğitimi, yetenekleri, kültürel çevre özellikleri gibi faktörler iş tatmini üzerinde etkilidir. Bu kişisel özellikler, her çalışanı diğer çalışandan farklı tutar. Örgütsel faktörler de, çift faktör teorisine göre bu iş özellikleri firma politikası, yönetilme şekli, takım arkadaşları ile ilişkiler, iş sağlığ1 ve güvenliği, ücret, çalışma koşulları, statü, işin gündelik hayatta bıraktığı etkisi, başarı, tanınma, kariyer planlamada yükselme, sorumluluk, mesleki ve kişisel gelişim firsatları ve işin kendi olarak belirtilmektedir (Reitz, 1987: 212). Yapılan araştırmalara göre bireylerin iş tatmininin sosyo-kültürel çevre faktörlerinden de etkilendiği ortaya çıkmıştır. Ailenin gelir düzeyi, eşlerin çalıştıkları iş yerlerindeki unvanları/statüleri, çalışan kadınların çocuklarının yaşları gibi sosyo-kültürel faktörlerinde iş tatmininde önemli farklılıklar ortaya çıkardığı görülmüştür. Çalışanların iş tatmini düzeyinin, verimlilik ve kâr ile doğrudan ilişkili olması sebebiyle firmalar, çalışanlarının iş tatminini sağlanmasında gerekli hassasiyeti göstermelidirler. Firmalar, çalışanların iş tatmini düzeyini belirleyerek, ilgili sektördeki ve firmadaki iş gücü devir oranlarının aşağı seviyelere çekilebilmesi için sürdürebilirliği sağlanacak çalışmalar yürütmelidirler.

Ülkemizde ve dünyada ilaç sektörüne verilen önem büyüktür. İlaç endüstrisi dünya ekonomisinde çok önemli bir paya sahiptir. Birçok ülke tarafından da desteklenen bir endüstri alanı olmuştur. Teknolojinin gelişmesi, ihtiyaçlardaki değişkenlik vb birçok sebepten dolayı ilaç sektörü çok dinamik bir yapıya sahiptir ve sahip olmak zorundadır. Maddi olarak yüksek bütçeli çalışmalar yapılmakta ve patentler alınmaktadır. Bu sektör için ürünlerin satışını yapan tıbbi mümessiller, tanıtım, yeni ilaç piyasa sürülmesi, satışlarının gerçekleştirilmesi de büyük rol oynarlar. Rekabetin maksimum düzeyde yaşandığı kuruluşlar arasında yerini alan ilaç satı̧̧ firmalarının, rakipleriyle arasındaki mücadelede önde olma, pazar liderliğini ele geçirme ve yüksek kârlılık sağlama gibi amaçlara ulaşabilmeleri için müşterilerinin memnuniyetini sağlamaları büyük önem arz etmektedir. Bu sektörde satış yapabilmenin temelini tıbbi mümesillerin yetenekleri ve kuracakları sağlıklı ve güvenilir diyaloglar oluşturmaktadır. Bu sebeple tıbbi mümessillerde iş tatmininin yüksek olması gerekir.

İlaç sektöründe satış alanın da çalışan tıbbi mümessillerin iş tatminini etkileyen faktörleri belirleyebilmek ve bu faktörlerin iş tatminini ile hangi ölçüde ilişkide olduğunu ortaya koyabilmek araştırmanın problemini oluşturmaktadır. Bu araştırmanın amacı, tıbbi mümessillerinin iş tatminini etkileyen kriterlerin istatistiksel analizler ve çok kriterli karar verme teknikleri ile belirlenmesi, kriterlerin iş tatmini ile arasındaki ilişkinin incelenmesidir. Araştırmada kullanılan ölçeklerin geçerliliğinin ve güvenilirliğinin sağlanmış olması, istatistiksel ve çok kriterli karar verme yöntemlerinden faydalanılarak kriterlerin belirlenmiş olması ve aynı zamanda bu sonuçlara göre ilaç sektöründe yer alan firmaların performansının da arttırılmasına yardımcı nitelikte olması araştırmanın önemini arttırmaktadır.

\section{1. İS TATMINI KAVRAMI VE ÖNEMI}

Günümüzde insan hayatının yoğun bir bölümün iş yerinde geçirildiği düşünüldüğünde, iş tatmininin yalnız iş hayatını değil sosyal hayatı da etkilediği görülmektedir (Smither, 1998). İş tatmini ile ilgili çalışmalarda, iş görenin sorunlarının saptanması, işle ilgili genel tutumun ve iletişimin sağlamlaştırılması, eğitim ihtiyaçlarının tespiti, yenilik ve değişim planlaması ve yönetilmesi gibi durumların düzenlenmesi işletmenin geleceği için büyük önem arz etmektedir (Davis ve Newstroom, 1989: 36). Tatmin olan kişilerin; işe gecikme yapmadıkları, işten ayrılma isteklerinin düşük olduğu, daha az sağlık problemleri geçirdikleri belirtilmektedir. Bu nedenle, iş tatmini sağlandığında işe katılım artacaktır. Tatmin olmamış iş görenle çalışan işletmelerde, iş aksatma, grev ve sendikal faaliyetlerde bulunmanın yanı sıra verimli çalışmama, disiplinsizlik gibi sorunlar görülebilmektedir (Erdoğan, 1996: 231). Bireylerin davranışlarına neden olan tutumlar incelendiğinde çok sayıda tutum ile karşılaşılmaktadır. Ancak örgütsel psikoloji, özellikle işletme yönetimiyle ilgili olarak büyük oranda iş tatmini ve örgüte bağlılık olmak üzere iki temel konu üzerinde odaklanmaktadır (Deniz, 2005: 308).

İş tatmini konusundaki araştırmalar insanları inceleyen psikoloji, sosyoloji, sosyal psikoloji ve antropoloji gibi bilim dalları arası yaklaşımların katkıları ile oluştuğundan, iş tatmini ile ilgili çeşitli tanımlar vardır. Lawler'ın görüşüne göre iş tatmini, kişinin hak ettiğini düşündüğü ile kendisine verilen arasındaki. farkın algısıdır. Yani bir çalışan hak ettiğini elde edemez ise, iş tatminsizliği ortaya çıkacaktır (Lawler, 1973: 107). İş tatmini neoklasik akımla birlikte ilgi odağı olmuş ve açığa çıkmıştır. Başlangıç olarak iş tatmini 1935'de Hoppock'un "İş Tatmini” adlı kitabı ile ilgiyi üzerine toplamıştır. Literatürde iş tatminine yönelik birçok farklı 
tanım yer almaktadır. İş tatmini çalışanın işi ile ilgili olumlu ya da olumsuz duygu birikimidir (Davis, Newstrom, 1985: 109). İş tatmini çalışanların işlerinden duydukları hoşnutluk veya memnun olmamadır (Davis, 1988: 96 ). İş tatmini kişinin tecrübeleriyle oluşan zevkli veya olumlu hisler şeklinde tanımlanabilir. Çalışanlar için önemli olan faktörlerin, işletmeler tarafindan ne düzeyde sağlanabildiğinin algılanması sonucu oluşan duygudur (Luthan, 1992: 114). İş tatmini “Çalışanların işine karşı gösterdiği genel tutumdur". İş tatmini işin çeşitli yönlerine karşı beslenen tutumların tümüdür. Elde edilen verilerin beklentilerin karşılanmasıyla alakalıdır (Erdoğan, 1996: 231-232). Farklı bir tanımda ise iş tatmini, bir çalışanın, işini ya da iş yaşamını değerlendirmesi sonucunda duyduğu haz ya da ulaştığı duygusal tatmin durumu olarak ifade edilmektedir (Başaran, 1991: 198).

İnsanlar çalışmaya başladıktan sonra zamanlarının büyük bir bölümünü işte geçirmektedirler. Bu bağlamda, yaptığı işten beklentisini karşılayan insan daha mutlu ve psikolojik olarak olumlu olabilmektedir. Dolayısıyla iş tatmini hem ekonomik hem de psikolojik açıdan çok önemlidir (Bakan ve Büyükmeşe, 2004: 6). Örgütlerin hedeflere ulaşı1masında en önemli bir faktör olan iş tatminin sağlanması ve yükseltilmesi için ilk başta iş tatminini sağlayan faktörlerinin neler olduğunun bilinmesi ve öğrenilmesi gerekir. İş görenin işe karsı olan tutumunu belirleyen faktörlerin herhangi birisi tek başına belirleyici olmaz. Çalışan personelin işe karsı tavrını belirleyen faktörler, bireysel, örgütsel ve sosyo kültürel çevre olarak 3 ana başlık altında toplanabilir (Tuta, 2008: 49). Bireysel faktörler, kişilerin özelliklerinden dolayı elde edecekleri tatmin seviyesini etkileyen kriterlerdir. Yaş, cinsiyet, medeni durum, eğitim düzeyi, mesleki konum ve kıdem, zekâ, hizmet zamanı ve benzeri etkenlerdir. Örgütsel faktörler ise işin kendisi, yönetim, yönetici ve denetim şekli, güvenlik hissi, iletişim, ücret, gelişme ve yükselme imkânları, rekabet, çalışma koşulları, iş arkadaşları ve örgütsel ortam olarak gruplandırılmaktadır (Akıncı, 2002: 6).

Bireysel faktörler açısından değerlendirildiğinde, yaşlı çalışanlar zamanla daha fazla alternatifle karşılaştıklarını gördükçe beklentilerini düşürmekte ve mevcut işlerden elde ettikleri tatmin seviyesi artmaktadır (Gazioğlu ve Tansel, 2006: 1168). Bovier ve Perneger (2003) cinsiyet ile yaş arasındaki tatmin düzeyine bakmışlar ve erkek tıp doktorların kadınlardan, Yaş olarak büyük tecrübeli doktorların, genç doktorlara göre iş tatmininin daha fazla olduğu belirtmiştir (Bovier ve Perneger, 2003: 301). Eren, güdülenmenin, bireyin hem tatmin hem de verimli olmasında önemli bir yeri olduğunu belirtmiştir (Eren, 2004: 254). Yapılan araştırmalar incelendiğinde cinsiyet faktörünün iş tatmini ile ilgili net bir sonuç ortaya çıkmamaktadır (Korman, 1978: 179; Ergeneli, Eryiğit, 2001: 36). Bazı çalışmalar kadın çalışan grupların iş tatmininin erkek çalışanlardan fazla olduğunu söylerken (İncir, 1990: 52), bazı çalışmalarda ise bunun tam tersi erkek çalışanların iş tatmininin fazla olduğunu belirtilmektedir (Bovier ve Perneger, 2003: 301; Uyargil, 1988: 23). Hatta farklı çalışmalarda ise erkek-kadın tatmin oranlarının eşit çıktığı görülmektedir. Bu farklılıkların sebebi birçok araştırmacıya göre meslek ile alakalıdır (Demir, 2007, 121). Burada dikkat edilmesi gereken bireylerin hangi mesleğe sahip olduğu, ne iş yaptığ 1 ve bireylerden beklentilerdir (Bender, Donohue ve Heywood, 2005: 480).

Literatürdeki araştırmalar incelendiğinde bireylerin medeni durumlarının iş tatminini hangi yönde ve hangi kuvvette etkilediğine dair kesin bulgulara rastlanmasa da, medeni durumu evli olan iş görenlerin, bekârlara oranla iş tatmininin yüksek olduğu ortaya konulmuştur. Bunun sebebi evli iş görenlerin daha fazla sorumluluklarının olması nedeniyle maddiyat ve ödüllere bekar iş görenlerden fazla önem ve değer verdikleri ile açıklanabilmektedir (Telman ve Ünsal, 2004: 59). Çalışanların aldığı eğitimlerin, başarı, statü, maddi ve maddi olmayan ödüller gibi beklentilerinin daha fazla olmasına sebep olduğu görülmektedir. Iş̧letmelerin bu tarz hedef ve beklentileri karşılayamadığı durumlarda çalışanların iş tatminleri olumsuz etkilenmektedir. $\mathrm{Bu}$ durum eğitim hayatına uzun yıllar devam etmiş çalışanların iş tatminlerin düşük olduğunu göstermektedir (Schultz ve Schultz, 1990: 281). Vecchio (1981) eğitimin beraberinde getirdiği iş tatminindeki farklılıkların sebebini beklentilerdeki farklılı̆ga bağlamaktadır (Metle, 2001: 315). Yaş ilerlemesiyle beraber, kişilerin emeklik yaşı yaklaştıkça, işlerinden duyulan tatminin büyük ölçüde arttığı belirtilmiştir. Geçmiş kariyerler incelendiğinde iş tatmininin daha çok arkadaşlık ve sosyal ilişkilerle sağlandığını düşünülmektedir (Davis, 1988: 46). Kişilik insanları birbirinden ayrıt eden davranışların tamamıdır. İkili ilişkileri zayıf, hayalci yapıya sahip ve çabuk sinirlenen insanların iş tatmini zayıf olma ihtimali yüksektir. Esnek, ne istediğini bilen kişiliğe sahip, sosyo-ekonomik değerleri yüksek, eğitim öğretim ile eğitim hayatını tamamlamış bireylerin daha çok iş tatmini sağladıkları görülmüştür (Locke, 1976: 1303).

İş tatminini en fazla etkileyen örgütsel unsurlar iş özellikleri, firma politikası, yönetilme şekli, takım arkadaşları ile ilişkiler, iş sağlığ ve güvenliği, ücret, çalışma koşulları, statü, işin gündelik hayatta bıraktı̆̆ 1 etkisi, başarı, tanınma, kariyer planlamada yükselme, sorumluluk, mesleki ve kişisel gelişim firsatları ve işin kendi olarak belirtilmektedir (Reitz, 1987: 212). 
İş gören işletme tarafından verilen ücret politikalarına ve almış olduğu eğitim, bilgi yeteneğine göre ücretlendirmeyi adil buluyorsa tatmin olacaktır (Robbins, 1996: 192). Sosyal yardım desteği, iş sağlığı ve güvenliği, sağlık hizmetleri, iş yerine geliş-gidişler, çalışma zamanları, ücretli ve ücretsiz izin süreleri, takım arkadaşları ile ilişkiler ve diğer sosyal ilişkiler, örgütsel moral motivasyon gibi çalışma hayatının tüm yönlerini çalışma şartları içinde düşünülebilir (Eroğlu, 2010: 326). Arkadaşlıklar olumlu dereceye ulaşmasında çalışama ortamı çalışanlar için çekici hale gelerek, iş tatmini düzeyi pozitif anlamda artacaktır (Eren, 2001, 40).tatmin edici bir işin nitelik açısından en önemli unsurları; işin farklılı̆̆ , ilgi çekiciliği, sıkıcı olmaması ve kariyer sağlamasıdır (Temir, 2002: 373). Yönetici, liderlik vasfını kullanarak, çalışanların amaca yönelik hedef gösterebilmelidir. Bu tutum çalışanların moralini pozitif yönde etkiler (Keser, 2006: 90).

Mosadeghrad ve Yarmohammadian (2006) 'a göre hastaneler de önem seviyesi daha yüksektir. İş tatmini sağlanmış sağlık çalışanlarına sahip olmak fayda ve yüksek kaliteli sağlık hizmetinin verilebilir (Kavuncubaşı, 2000: 292). Yapılan çalışmalar sağlık sektöründe çalışanların iş tatminsizliği varsa stres artar ve sonucunda davranış bozuklukları, çatışma, bağlı olduğu kuruma inancı azalır, hastanın iyileşme zamanında artış gibi negatif sonuçlar meydana getirir (Karahan, 2009: 271). Literatür incelendiğinde sağlık sektöründe yapılan çalışmaların genellikle hastane ortamında çalışanların iş tatmini üzerine odaklandığı, bazı çalışmalarda da tıbbi mümessillerin iş tatmini sonuçlarının farklı ölçekler yardımıyla belirlendiği görülmektedir (Keleş ve Çelik, 2006; Varol, Karaer ve Ortakarpuz, 2017; Yılmaz, 2006). Ancak ilaç sektöründe satış alanının da çalışan tıbbi mümessillerin iş tatminini etkileyen faktörleri çok kriterli karar verme yöntemleri ile belirleyen çalışmalara rastlanmamıştır.

\section{ARASTIRMANIN YÖNTEMI}

Literatürde kriterlerin ağırlıklarını belirlemek için birçok yöntem geliştirilmiştir. Bu yöntemlerden biri de Saaty tarafından geliştirilen Analitik Hiyerarşi Sürecidir (AHP) (Saaty, 1990) Analitik hiyerarşi süreci karar almada, birey veya grupların önceliklerini de dikkate alan, nicel ve nitel değişkenleri bir araya toplayarak değerlendirebilen bir matematiksel yöntemdir (Dağdeviren ve diğerleri, 2005). AHP yaklaşımı, bir grup karar vericinin sağladığı hiyerarşi ve yargısal verilerin tutarlılığını önceliklendiren bir ölçüm teorisidir (Saaty, 1980). AHP modeli, tüm uzmanların değerlendirmelerini, alternatiflerin ikili karşılaştırmalarıyla kullanılan öznel ölçütlerini kullanmadan nihai bir karara dahil eder. Genel olarak, AHP yaklaşımı, karmaşık bir karar problemini basit bir hiyerarşi sürecine dönüştürmek için tasarlanmış bir puanlama metodudur ve daha sonra basit çift-yönlü karşılaştırmalar yaparak, hiyerarşinin her seviyesinde bir ağırlığı oluşturmaktadır (Saaty, 1990).

Kavramsal bir temel için AHP modelleme süreci dört aşamadan oluşur; karar probleminin yapılandırılması, ölçüm tekniği, veri toplama, normalize edilmiş ağırlıkların belirlenmesi ve problemin sentez çözümünün bulunmasidır (Tummala ve Wan, 1994).

İkili karşılaştırma matrisi A'nın kurulması; $\mathrm{C}_{1}, \mathrm{C}_{2}, \ldots, \mathrm{Cn}$ 'nin bir dizi öğeyi temsil etmektedir. İki unsurun göreceli önemi 1, 3, 5, 7 ve 9 değerlerine sahip bir ölçek kullanılarak derecelendirilmektedir. Burada 1 "eşit derecede önemli", 3 "biraz daha önemli", 5 "çok daha önemli”, 7 "gösterilebilir derecede daha önemli" ve 9 "kesinlikle daha önemli" anlamına gelmektedir. Bu ölçekler A matisi adıyla bir $\mathrm{n} \times \mathrm{n}$ matris şeklinde gösterilmektedir.

$\mathrm{C}_{1}, \mathrm{C}_{2}, \ldots, \mathrm{C}_{\mathrm{n}}$ kriterlerinin ikili karşılaştırma değerlerini oluşturan $a_{i j}=1$ ve $a_{i j}=1 / a_{i j}, i, j=1,2 \mathrm{~K}, n$. şeklindedir. $C_{1}, C_{2}, \mathrm{~K}, C_{n}$ karşılaştırmalardan oluşan A matrisi ağırlıkları $W_{1}, W_{2}, \mathrm{~K}, W_{n}$ şeklinde oluşur.

$$
A=\left[a_{i j}\right]=\begin{gathered}
C_{1} \\
C_{2} \\
\mathrm{M} \\
C_{n}
\end{gathered}\left[\begin{array}{cccc}
1 & a_{12} & \Lambda & a_{1 n} \\
1 / a_{12} & 1 & \Lambda & a_{2 n} \\
\mathrm{M} & \mathrm{M} & \mathrm{O} & \mathrm{M} \\
1 / a_{1 n} & 1 / a_{2 n} & \Lambda & 1
\end{array}\right] .
$$

Saaty en büyük özdeğeri $\lambda_{\max }$ şeklinde tanımlamıştır ve hesaplanması;

$$
\lambda_{\max }=\sum_{j=1}^{n} a_{i j} \frac{W_{j}}{W_{i}} .
$$

Saaty, karşılaştırma matrisinin tutarlılı̆̆ını doğrulamak için tutarlılık indeksi (CI) ve tutarlılık oranını (CR) kullanmayı önermiştir. CI ve CR aşağıdaki gibi tanımlanır: 
$C I=\left(\lambda_{\max }-n\right) /(n-1)$,

$C R=C I / R I$,

Burada, RI, aynı mertebeden karşı1lıklı matrislerin rastsal olarak ortalama tutarlılık endeksini temsil eder.

$\mathrm{CR} \leqq 0,1$, değerinin elde edilmesi matrisin tutarlılı̆ının yeterli olduğunu göstermektedir.

\section{ARAŞTIRMANIN BULGULARI}

$\mathrm{Bu}$ çalışmanın amacı, ilaç sektöründe çalışan tıbbi mümessillerin iş tatminini etkileyen kriterlerin tespit edilmesi ve çok kriterli karar verme yöntemlerinden AHP ile önceliklerinin sıralandırılması, kriterler ile iş tatmini arasındaki ilişkilerin belirlemesidir. Bu amaçla literatür araştırması ve tıbbi mümessillerle yapılan beyin firtınası sonucunda araştırma kriterleri belirlenmiştir. Araştırmada belirlenen kriterler; cinsiyet, yaş grubu, eğitim durumu, medeni durum, çocuk sayısı, unvan, günlük ortalama fiili çalışma süresi, ilaç sektöründe çalışılan toplam yıl1, istihdam sözleşmesi, tecrübe, aylık gelir durumu, yan ödemeler, firma türü (ulusal, uluslararası), terfi durumu, yöneticinin faktörü, ödüllendirme, çalışma şartları, iş arkadaşları, işin kendisi ve iletişimdir.

Araştırma Kayseri ilinde ikamet eden tıbbi mümessillere yönelik 2016 yılı Şubat ve Mart ayları arasındaki süreçte yapılan anket uygulamasıyla gerçekleştirilmiştir. Tıbbi mümessiller derneği (TIMMBİR) ile yapılan görüşmelere istinaden Kayseri'de toplam 300 civarında tıbbi mümessil olduğu öğrenilmiştir. Bu evren içerisinde örneklem büyüklüğünü belirlemek amacıyla hazır bir tablo kullanılmıştır (Yazıcıoğlu ve Erdoğan, 2004, s.50). Örneklem büyüklüğü tablosu incelendiğinde evrenin 300, hata payının \% 10 kabul edildiği takdirde gerekli örneklem büyüklügü 73 olarak tespit edilmiştir. Yaklaşık 80 anket formunun hazırlanarak uygulandığ1 araştırmada, veriler yüz yüze anket yöntemiyle toplanmıştır. Çalışmada tesadüfi olmayan örnekleme yöntemlerinden kolayda örnekleme yöntemi kullanılmıştır. Doldurulan anketler gözden geçirilerek \%94 kullanılabilir oranı ile 76 anketinin analizlerde kullanılmasına karar verilmiştir. Hazırlanmış olan anket üç bölümden oluşmaktadır. Birinci bölümde demografik özelliklere yönelik soru seti oluşturulmuş, ikinci bölümde iş tatmininin ölçülmesi için Spector ölçeği kullanılmış (Spector,1997) ve üçüncü bölümde iş tatminini etkileyen kriterlerin tespiti için Saaty tarafından önerilen ikili karşılaştırma testleri yapılmıştır. Cronbach $\alpha$ değeri $(0,901) 0,9$ 'dan büyük olduğu için ölçek çok iyi derecede güvenilirdir. Ankete katılanların çoğunluğu erkek (\% 90) ve \% 47.4'ü 31-40 yaş aralığındadır. İlaç satış mümessillerinin \% 61.8'inin medeni durumu evlidir. İlaç mümessillerinin \% 72.4'ü üniversite mezunu, \% 50'sinin 1501-2500 TL arasında geliri ve \% 60.5'i 1-5 yıl aralığında firmalarında tecrübesi bulunmaktadır. İlaç mümessillerinin \% 31.6'sının bir yada iki çocuğu olmakta, \% 90.8'i uzman olarak görev almakta, \% 27.6'sı 1-5 yıla kadar tecrübeli, \% 59.2'si kalıcı istihdam sözleşmesi ile çalışmaktadır. İlaç mümessillerinin \% 94.7'sinin ek imkanı bulunmakta ve \% 80.3'ü maaş artı prim olarak çalıştığı görülmüştür. Elde edilen değişkenlere ilişkin tanımlayıcı istatistikler Tablo.1'te verilmiştir. 
Tablo 1: Demografik Özelliklere Ait İstatistikler

\begin{tabular}{|c|c|c|c|c|c|c|c|c|c|}
\hline FAKTÖR & $\begin{array}{c}\text { ALT } \\
\text { FAKTÖR }\end{array}$ & Frekans & Yüzde & $\begin{array}{l}\text { Kümülatif } \\
\text { Yüzde }\end{array}$ & FAKTÖR & ALT FAKTÖR & Frekans & Yüzde & $\begin{array}{c}\text { Kümülatif } \\
\text { Yüzde }\end{array}$ \\
\hline \multirow{3}{*}{ CINSIYYET } & Kadın & 36 & 47,4 & 47,4 & \multirow{6}{*}{ TECRÜBE } & 1 yildan az & 10 & 13,2 & 13,2 \\
\hline & Erkek & 40 & 52,6 & 100 & & $1-5$ & 21 & 27,6 & 40,8 \\
\hline & Toplam & 76 & 100 & & & $6-10$ & 19 & 25 & 65,8 \\
\hline \multirow{5}{*}{$\begin{array}{l}\text { YAŞ } \\
\text { GRUBU }\end{array}$} & $18-30$ & 27 & 35,5 & 35,5 & & $11-15$ & 13 & 17,1 & 82,9 \\
\hline & $31-40$ & 36 & 47,4 & 82,9 & & 16 ve üzeri & 13 & 17,1 & 100 \\
\hline & $41-50$ & 12 & 15,8 & 98,7 & & Toplam & 76 & 100 & \\
\hline & \begin{tabular}{|l|}
$51-60$ \\
\end{tabular} & 1 & 1,3 & 100 & \multirow{6}{*}{$\begin{array}{l}\text { KURUM } \\
\text { TECRÜBE }\end{array}$} & 1 y1ldan az & 13 & 17,1 & 17,1 \\
\hline & Toplam & 76 & 100 & & & $1-5$ & 46 & 60,5 & 77,6 \\
\hline \multirow{5}{*}{$\begin{array}{l}\text { EGİTIM } \\
\text { DURUMU }\end{array}$} & İlköğretim & 1 & 1,3 & 1,3 & & $6-10$ & 11 & 14,5 & 92,1 \\
\hline & Lise & 3 & 3,9 & 5,3 & & $11-15$ & 3 & 3,9 & 96,1 \\
\hline & Üniversite & 55 & 72,4 & 77,6 & & 16 ve üzeri & 3 & 3,9 & 100 \\
\hline & Lisans Üstü & 17 & 22,4 & 100 & & Toplam & 76 & 100 & \\
\hline & Toplam & 76 & 100 & & \multirow{3}{*}{$\begin{array}{l}\text { SÖZLEŞME } \\
\text { TURU }\end{array}$} & Kalıc1 & 45 & 59,2 & 59,2 \\
\hline \multirow{3}{*}{$\begin{array}{l}\text { MEDENI } \\
\text { DURUM }\end{array}$} & Bekar & 29 & 38,2 & 38,2 & & Geçici & 31 & 40,8 & 100 \\
\hline & \begin{tabular}{|l|} 
Evli \\
\end{tabular} & 47 & 61,8 & 100 & & Toplam & 76 & 100 & \\
\hline & Toplam & 76 & 100 & & \multirow{6}{*}{ GELİR } & $1500 \mathrm{TL}$ ve alt1 & 2 & 2,6 & 2,6 \\
\hline \multirow{6}{*}{$\begin{array}{l}\text { ÇOCUK } \\
\text { SAYISI }\end{array}$} & Yok & 5 & 6,6 & 6,6 & & 1501-2500TL & 38 & 50 & 52,6 \\
\hline & 1 & 24 & 31,6 & 38,2 & & 2501-3000TL & 14 & 18,4 & 71,1 \\
\hline & 2 & 24 & 31,6 & 69,7 & & 3001-4000TL & 18 & 23,7 & 94,7 \\
\hline & 3 & 20 & 26,3 & 96,1 & & 4001TL ve üzeri & 4 & 5,3 & 100 \\
\hline & 4 & 3 & 3,9 & 100 & & Toplam & 76 & 100 & \\
\hline & Toplam & 76 & 100 & & \multirow{3}{*}{ EK İMKAN } & Var & 72 & 94,7 & 94,7 \\
\hline \multirow{4}{*}{ ÜNVAN } & Uzman & 69 & 90,8 & 90,8 & & Yok & 4 & 5,3 & 100 \\
\hline & Müdür & 4 & 5,3 & 96,1 & & Toplam & 76 & 100 & \\
\hline & Genel Müdür & 3 & 3,9 & 100 & \multirow{3}{*}{$\begin{array}{l}\text { FİRMA } \\
\text { TURU }\end{array}$} & Yerli & 38 & 50 & 50 \\
\hline & Toplam & 76 & 100 & & & Yabanc1 & 38 & 50 & 100 \\
\hline \multirow{6}{*}{$\begin{array}{l}\text { ÇALISMA } \\
\text { SÜRESI }\end{array}$} & $0-2$ & 9 & 11,8 & 11,8 & & Toplam & 76 & 100 & \\
\hline & $3-5$ & 19 & 25 & 36,8 & \multirow{3}{*}{$\begin{array}{l}\text { ÜCRET } \\
\text { SİSTEMİ }\end{array}$} & Maaş & 15 & 19,7 & 19,7 \\
\hline & $6-8$ & 19 & 25 & 61,8 & & Maaş+Prim & 61 & 80,3 & 100 \\
\hline & 9-10 & 28 & 36,8 & 98,7 & & Toplam & 76 & 100 & \\
\hline & 11 ve üzeri & 1 & 1,3 & 100 & & & & & \\
\hline & Toplam & 76 & 100 & & & & & & \\
\hline
\end{tabular}

Çalışmanın ikinci bölümünde kullanılan Spector İş tatmini ölçeğine yönelik sonuçlar Tablo.2'de sunulmuştur. Spector ölçeğine göre elde edilen ortalamalar ve ve genel iş tatmini ortalamalası incelendiğinde; genel iş tatmini ortalamas 3,06 olarak orta düzeyde elde edilmiştir. Alt kriterlerin ortalaması incelendiğinde ise en yüksek tatmin olunan kriterin işin kendisi $(3,72)$ olduğu görülmüştür. Diğer kriterlerden tatmin seviyesi ise sırasıyla iletişim $(3,58)$, iş arkadaşları $(3,42)$, yan ödemeler $(3,13)$, yönetici $(3,09)$, ödüllendirmeler $(3,04)$, çalışma şartları $(2,78)$, terfi $(2,54)$, ücret $(2,41)$ 'dir. 
Tablo 2: SPECTOR Ölçeği Özet Tablosu

\begin{tabular}{|c|c|c|c|}
\hline DEĞISSTKENLER & $\mathbf{n}$ & Ortalama & Standart Sapma \\
\hline Yaptığım işe karşı aldığım ücret miktarının adaletli olduğuna inanıyorum & 76 & 2,38 & 1,336 \\
\hline Firmamda ücret artış sıklı̆̆ından memnunum & 74 & 2,20 & 1,216 \\
\hline Bana ödenen ücreti düşündüğümde firma tarafindan beğenildiğimi düşünüyorum & 76 & 2,86 & 1,363 \\
\hline Ücretlerin artış oranlarından memnunum & 75 & 2,19 & 1,216 \\
\hline Ucret Ortalaması & 76 & 2,4112 & $\mathbf{1 , 0 1 4 7 4}$ \\
\hline İlerleme ve terfi olanakları memnun edicidir & 69 & 2,17 & 1,236 \\
\hline İşini iyi yapan kişilerin adaletli bir şekilde terfi olma şansları bulunmaktadır. & 75 & 2,36 & 1,382 \\
\hline Firmamda çalışanlar diğer firmalarda çalışanlar kadar hızlı ilerlemektedir & 75 & 2,73 & 1,277 \\
\hline Çalışanlar yükselmek için eşit şansa sahiptirler. & 76 & 2,79 & 1,170 \\
\hline Terfi Ortalaması & 76 & 2,5471 & $\mathbf{1 , 0 3 3 5 4}$ \\
\hline Yöneticim işinde oldukça yeteneklidir. & 70 & 2,73 & 1,273 \\
\hline Yöneticim bana göre adaletli davranmaktadır & 75 & 3,23 & 1,351 \\
\hline Yöneticimin bana gösterdiği ilgi kendimi önemli bir kişi gibi hissetmemi sağlamaktadır & 76 & 3,41 & 1,202 \\
\hline Yöneticimi beğeniyorum & 76 & 2,93 & 1,147 \\
\hline Yönetici Ortalaması & 76 & 3,0954 & ,94091 \\
\hline Aldığım ücret dışı yan ödemeler tatmin edicidir & 76 & 3,16 & 1,020 \\
\hline Firmamda elde ettiğim yan gelirler diğer firmaların çoğunda çalışanların aldıkları kadardır & 72 & 3,33 & 2,659 \\
\hline Firmamda yan ödemelerde adaletli davranılmaktadır & 76 & 2,66 & 1,260 \\
\hline Almam gereken yan ödemelere sahip olabiliyorum & 76 & 3,42 & 1,123 \\
\hline Yan Ödemeler Ortalaması & 76 & 3,1316 & ,94440 \\
\hline İşimi iyi yaptığımda yeterince tanınma imkânım olmaktadır & 76 & 3,58 & 1,086 \\
\hline Yaptığım işin beğenildiğini hissediyorum & 74 & 3,38 & 1,190 \\
\hline Firmamda ödüllendirmeler sık sık yapılmaktadır & 76 & 2,36 & 1,230 \\
\hline Çabalarımın yeterince ödüllendirildiğini düşünüyorum & 76 & 2,91 & 1,110 \\
\hline Ödüllendirmeler Ortalaması & 76 & 3,0493 & ,79059 \\
\hline Kural ve prosedürlerin çoğu iyi bir iş yapmayı kolaylaştırmaktadır & 76 & 2,89 & 1,206 \\
\hline İyi bir iş yapmak için çabalarım bürokrasi tarafından engellenmemektedir & 76 & 2,32 & 1,134 \\
\hline İşim gereği çok fazla çalışmak zorunda kalmıyorum & 76 & 2,87 & 1,204 \\
\hline Çalışmam gereken çok fazla evrağım (dokümanım) bulunmamaktadır. & 76 & 3,07 & 1,247 \\
\hline Çalışma Şartları Ortalaması & 76 & 2,7862 & ,66421 \\
\hline İş arkadaşlarımdan memnunum & 76 & 3,80 & 1,178 \\
\hline İşlerinde yeterli kişilerle çalıştığımdan çok fazla çalışmak zorunda kalmıyorum & 76 & 3,26 & 1,136 \\
\hline İşimi yapmamda bana yardımcı olan işgörenden (büro elemanı vb.) memnunum & 75 & 3,27 & 1,359 \\
\hline İşyerinde çalışanlar arasında çok fazla çatışma yaşanmamaktadır & 74 & 3,35 & 1,175 \\
\hline İş arkadaşları ortalaması & 76 & 3,4243 & ,83768 \\
\hline Yaptığım işin çok anlamlı olduğunu düşünüyorum & 73 & 3,88 & 1,269 \\
\hline Çalışma süremdeki boş zamanlarımda işimle ilgili daha fazla çalışmaktan hoşlanıyorum & 76 & 3,36 & 1,272 \\
\hline Yaptığım işten gurur duyuyorum & 76 & 3,78 & 1,207 \\
\hline İşimin zevkli olduğuna inanmaktayım & 75 & 3,87 & 1,143 \\
\hline İşin kendisinin ortalaması & 76 & 3,7292 & $\mathbf{1 , 0 2 3 7 1}$ \\
\hline İşletmemde genel olarak iyi bir iletişim ortamı vardır & 76 & 3,70 & 1,132 \\
\hline İşletmemin amaçları bana göre yeterince açıktır & 76 & 3,61 & 1,072 \\
\hline İşletmemde neler olduğu hakkında genellikle bilgim olmaktadır & 76 & 3,54 & 1,101 \\
\hline İşimle ilgili görevlerim tam olarak açıklanmıştır & 76 & 3,50 & 1,260 \\
\hline İletişim ortalaması & 76 & $\mathbf{3 , 5 8 5 5}$ & ,85005 \\
\hline İŞ TATMINİ ORTALAMASI & 76 & 3,0603 &, $\mathbf{5 8 3 6 4}$ \\
\hline
\end{tabular}

Varyans analizinde ise hipotezler tüm değişkenler için " $\mathrm{H}_{0}=$ İş tatmini ile kriterler arasında istatistiksel olarak anlamlı bir farklılık yoktur" şeklinde belirlenmiştir. Varyans analizi sonuçları Tablo.3'de verilmiştir. Gelir grupları ile iş tatmini $(\mathrm{p}=0,028)$ ve Ek imkan ve iş tatmini $(\mathrm{p}=0,023)$ arasında istatistiksel olarak anlamlı bir farklılık olduğu görülmüştür. 
Tablo 3: Varyans Analizi

\begin{tabular}{|c|c|c|c|c|c|c|}
\hline \multicolumn{2}{|l|}{ KRITTER } & Kareler Toplam1 & Serbestlik Derecesi & Kareler Ortalamas1 & $\mathrm{F}$ & $\mathrm{p}$ \\
\hline \multirow{3}{*}{ CINSIYET } & Gruplar Arasında & 13,424 & 47 & 0,286 & \multirow{3}{*}{1,448} & \multirow{3}{*}{0,149} \\
\hline & Gruplar İçinde & 5,524 & 28 & 0,197 & & \\
\hline & Toplam & 18,947 & 75 & & & \\
\hline \multirow{3}{*}{ YAŞ GRUBU } & Gruplar Arasında & 29,576 & 47 & 0,629 & \multirow{3}{*}{1,573} & \multirow{3}{*}{0,101} \\
\hline & Gruplar İçinde & 11,2 & 28 & 0,4 & & \\
\hline & Toplam & 40,776 & 75 & & & \\
\hline \multirow{3}{*}{ EGİTIMM DURUMU } & Gruplar Arasında & 16,381 & 47 & 0,349 & \multirow{3}{*}{1,705} & \multirow{3}{*}{0,067} \\
\hline & Gruplar İçinde & 5,724 & 28 & 0,204 & & \\
\hline & Toplam & 22,105 & 75 & & & \\
\hline \multirow{3}{*}{ MEDENİ DURUM } & Gruplar Arasında & 12,277 & 47 & 0,261 & \multirow{3}{*}{1,293} & \multirow{3}{*}{0,236} \\
\hline & Gruplar İçinde & 5,657 & 28 & 0,202 & & \\
\hline & Toplam & 17,934 & 75 & & & \\
\hline \multirow{3}{*}{ COCUK SAYISI } & Gruplar Arasında & 53,729 & 47 & 1143 & \multirow{3}{*}{1,494} & \multirow{3}{*}{0,129} \\
\hline & Gruplar İçinde & 21,429 & 28 & 0,765 & & \\
\hline & Toplam & 75,158 & 75 & & & \\
\hline \multirow{3}{*}{ ÇALIŞMA SURESI } & Gruplar Arasında & 54,998 & 47 & 1,17 & \multirow{3}{*}{1,045} & \multirow{3}{*}{0,46} \\
\hline & Gruplar İçinde & 31,357 & 28 & 1,12 & & \\
\hline & Toplam & 86,355 & 75 & & & \\
\hline \multirow{3}{*}{ TECRÜBE } & Gruplar Arasında & 91,533 & 47 & 1948 & \multirow{3}{*}{1,585} & \multirow{3}{*}{0,098} \\
\hline & Gruplar İçinde & 34,414 & 28 & 1229 & & \\
\hline & Toplam & 125,947 & 75 & & & \\
\hline \multirow{3}{*}{ KURUM TECRÜBE } & Gruplar Arasında & 44,886 & 47 & 0,955 & \multirow{3}{*}{1,683} & \multirow{3}{*}{0,072} \\
\hline & Gruplar İçinde & 15,89 & 28 & 0,568 & & \\
\hline & Toplam & 60,776 & 75 & & & \\
\hline \multirow{3}{*}{ SÖZLEŞME TÜRÜ } & Gruplar Arasında & 13,008 & 47 & 0,277 & & \\
\hline & Gruplar İçinde & 5,348 & 28 & 0,191 & 1,449 & 0,148 \\
\hline & Toplam & 18,355 & 75 & & & \\
\hline & Gruplar Arasında & 58,908 & 47 & 1253 & & \\
\hline GELİR & Gruplar İçinde & 17,724 & 28 & 0,633 & 1,98 & 0,028 \\
\hline & Toplam & 76,632 & 75 & & & \\
\hline & Gruplar Arasında & 2,932 & 47 & 0,062 & & \\
\hline EK İMKAN & Gruplar İçinde & 0,857 & 28 & 0,031 & 2,038 & 0,023 \\
\hline & Toplam & 3,789 & 75 & & & \\
\hline & Gruplar Arasında & 13,486 & 47 & 0,287 & & \\
\hline FİRMA TÜRÜ & Gruplar İçinde & 5,514 & 28 & 0,197 & 1,457 & 0,145 \\
\hline & Toplam & 19 & 75 & & & \\
\hline & Gruplar Arasında & 6,578 & 47 & 0,14 & & \\
\hline UCRET SİSTEMİ & Gruplar İçinde & 5,462 & 28 & 0,195 & 0,717 & 0,845 \\
\hline & Toplam & 12,039 & 75 & & & \\
\hline
\end{tabular}

İkili karşılaştırma anketinde iş tatmini etkileyen 9 kriter, uzman görüşleri doğrultusunda 5'i temel ve 4'ü yan kriter olmak üzere belirlenmiştir. Tablo 4'de tıbbi mümessillerin vermiş olduğu ikili karşılaştırma anket değerlendirmelerinin geometrik ortalamaları verilmiş̧ir. 
Tablo 4: Anket Sonuçlarının Geometrik Ortalamaları

\begin{tabular}{|c|c|c|c|}
\hline SORU NO & KRITTER & KRITER & GEOORT \\
\hline K1 & ÜCRET & TERFİ & 0,836851 \\
\hline $\mathbf{K 2}$ & ÜCRET & ÖDÜLLENDİRME & 0,627022 \\
\hline K3 & ÜCRET & ÇALIŞMA ŞARTLARI & 1,002395 \\
\hline K4 & ÜCRET & İşìN KENDİSİ & 0,855718 \\
\hline K5 & TERFİ & ÖDÜLLENDİRME & 1,435371 \\
\hline K6 & TERFI & ÇALIŞMA ŞARTLARI & 1,16369 \\
\hline K7 & TERFI & İşì KENDİSI & 1,586024 \\
\hline K8 & ÖDÜLLENDİRME & ÇALIŞMA ŞARTLARI & 1,660218 \\
\hline K9 & ÖDÜLLENDİRME & İşìn KENDİSİ & 1,426375 \\
\hline K10 & ÇALIŞMA ŞARTLARI & İşín KENDISİ & 1,375425 \\
\hline K11 & YÖNETİCI & YAN ÖDEMELER & 0,931379 \\
\hline K12 & YÖNETICİ & İş ARKADAŞLARI & 0,759109 \\
\hline K13 & YÖNETICİ & İLETIŞiM & 1,023593 \\
\hline K14 & YAN ÖDEMELER & İş ARKADAŞLARI & 1,015306 \\
\hline K15 & YAN ÖDEMELER & İLETIŞiM & 1,186874 \\
\hline K16 & İŞ ARKADAŞLARI & İLETIŞì & 1,399932 \\
\hline K17 & TEMEL KRİTERLER & YAN KRİTERLER & 0,880257 \\
\hline
\end{tabular}

İkili karşılaştırmalar sonucunda elde edilen kriterlerin geometrik ortalamaları Superdecisions paket programı kullanılarak modellenmiş ve analiz edilmiştir. İş tatminini etkileyen kriterler için hazırlanan Çok kriterli Çalışmanın modeli Şekil 1'de gösterilmiştir.

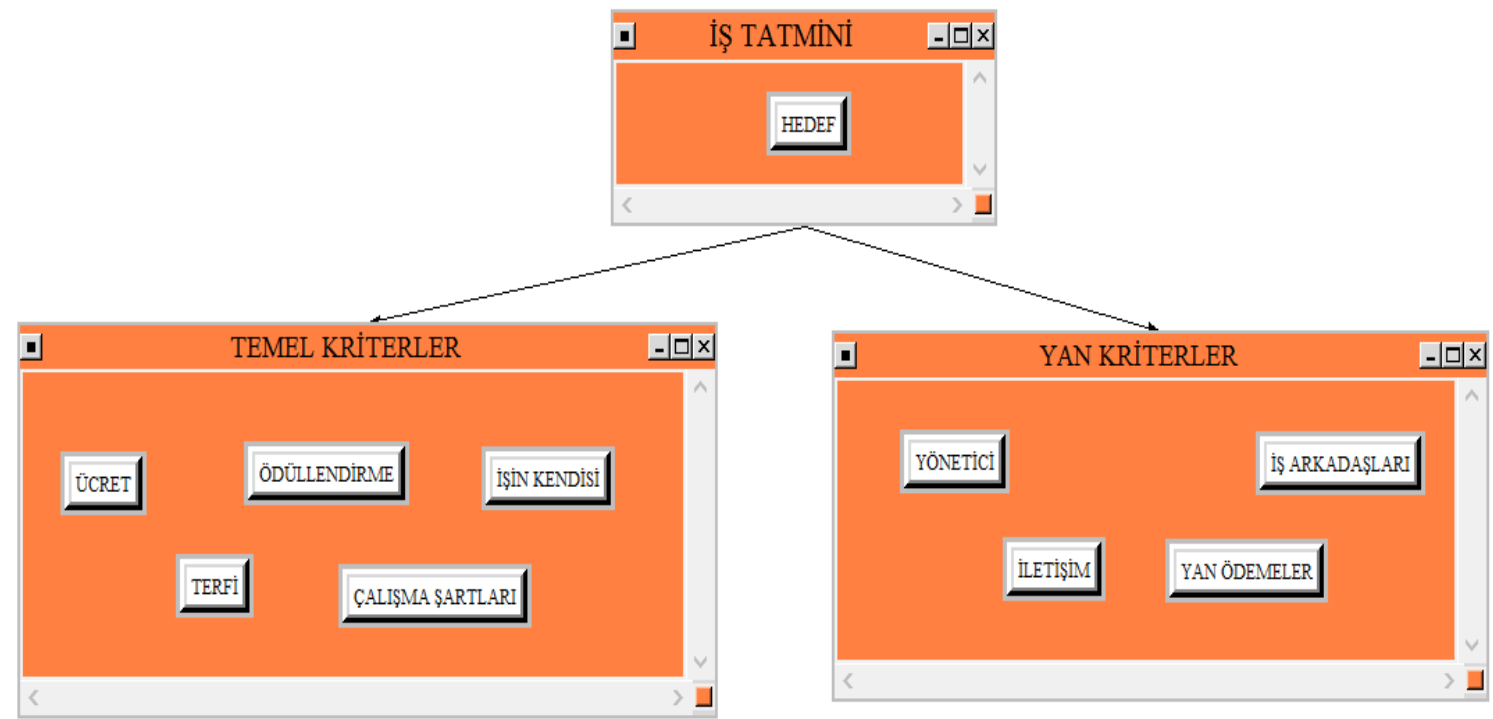

\section{Şekil 1:Çalışmanın Modeli}

Bütün etkileyen faktör kümeleri için tutarsızlık oranı hesaplanmış ve Şekil.1'de temel değişken grubu için 0,01479 ve Şekil.2'de yan kriter grubu için 0,00199 olarak elde edilmiștir. Her iki değișken grubunda da oran 0.1 üst değerinin altında kaldığı için ölçek tutarlıdır. Şekil.3'de ise temel ve yan kriterlerin karşılaştırma matrisi yer almaktadır. 


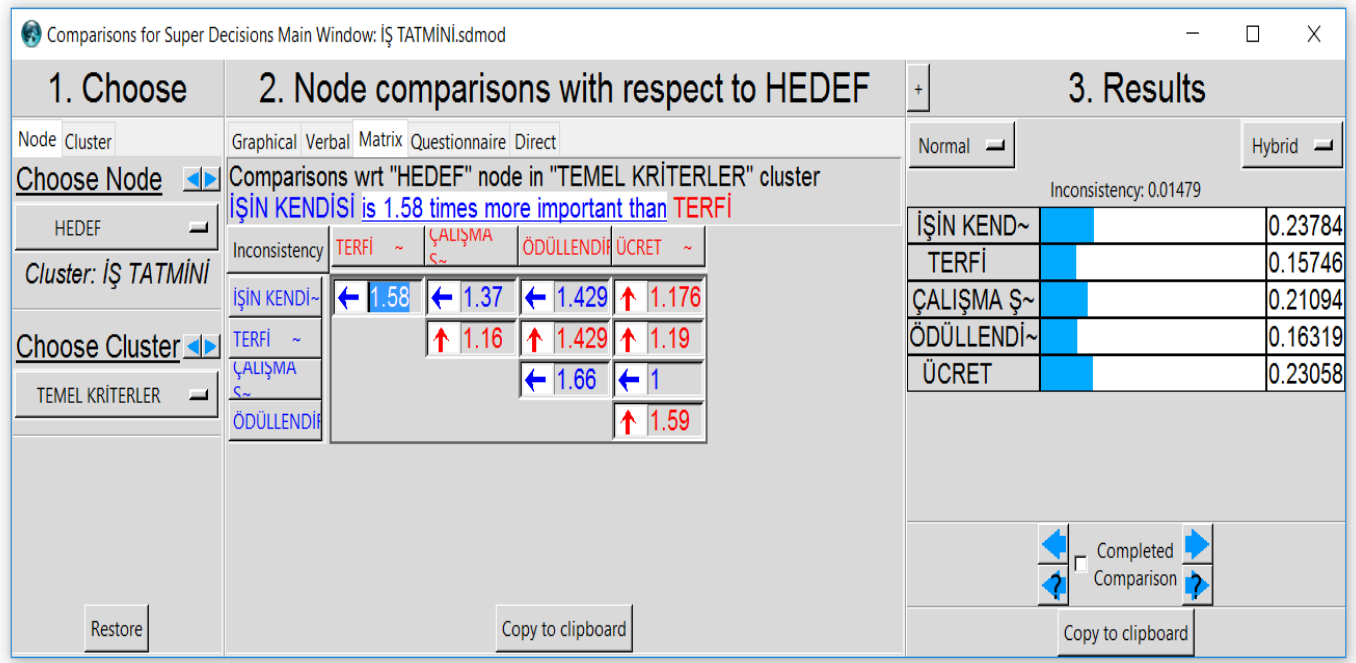

Şekil 2: Superdecisions Temel Kriterler Karşılaştırma Matrisi

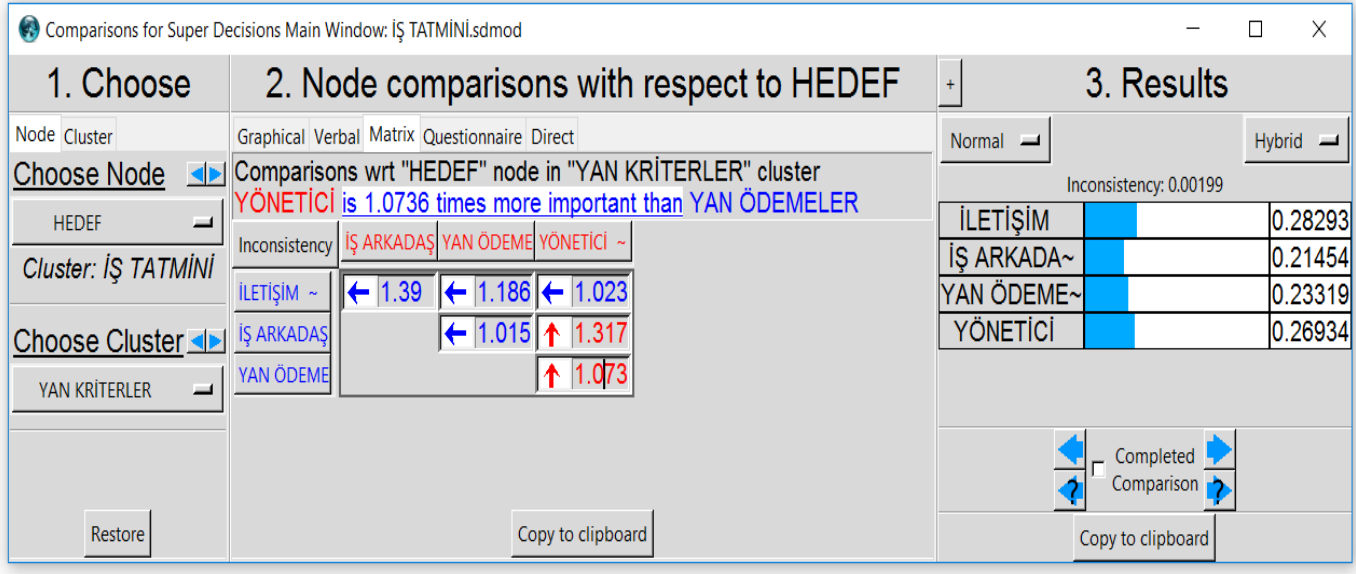

Şekil 3:Superdecisions Yan Kriterler Karşılaştırma Matrisi

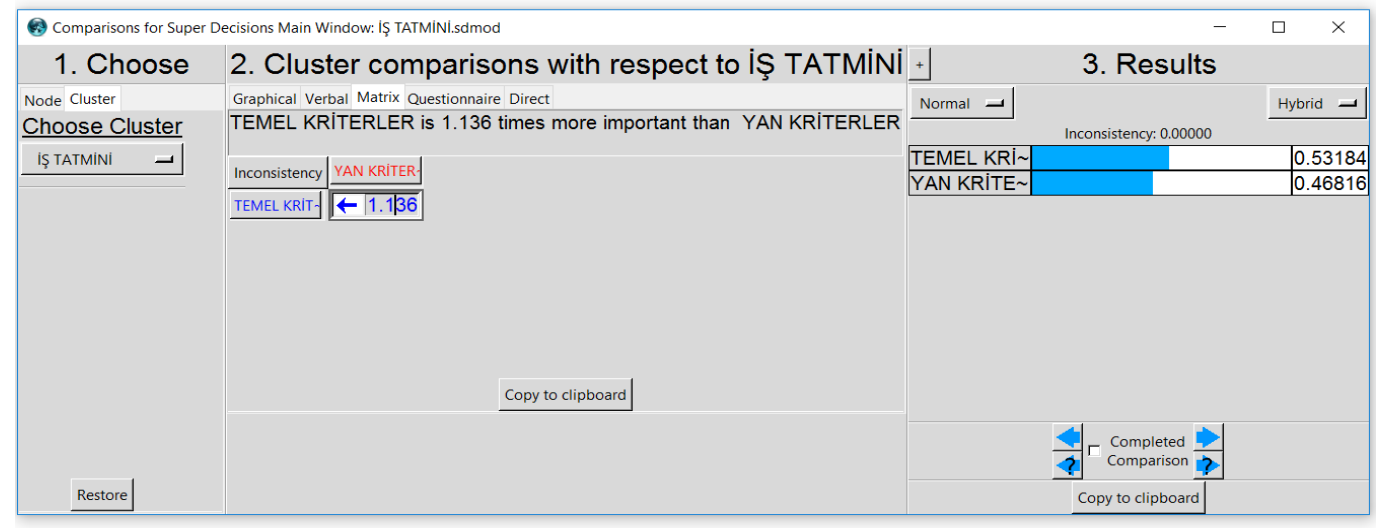

Şekil 4:Temel- Yan Kriterler Karşılaştırma Matrisi 
Şekil.4'de Superdecisions programından faydalanılarak oluşturulan ağırlıklandırılmış süpermatris sonucunda kriterlerin ağırlıkları elde edilmiştir. Şekil.5'de yer alan kriter önceliklendirme sonuçlarının değerlendirmesiyle sıralamada yer alan ilk 5 kriter ve ağırlıkları aşağıdaki gibidir;
I. İletişim
$13.24 \%$
II. Yönetici
$12.64 \%$
III. İșin kendisi
$12.60 \%$
IV. Ücret
$12.26 \%$
V. Çalışma Şartları
$11,21 \%$

\begin{tabular}{|c|c|c|c|c|}
\hline 3 Supe & er Decisions Main Wi & Amod: Pr... & $\square$ & \\
\hline \multicolumn{5}{|c|}{ Here are the priorities. } \\
\hline Icon & Name & Normalized by Cluster & $=\overline{\text { Limiting }}$ & - \\
\hline No Icon & HEDEF & $\longdiv { 0 . 0 0 0 0 0 }$ & 0.000000 & \\
\hline No Icon & UCRET & 0.23058 & $\longdiv { 0 . 1 2 2 6 3 0 }$ & \\
\hline No Icon & TERFi & 0.15745 & 0.083740 & \\
\hline No Icon & ODULLENDIRME & 0.16319 & 0.086790 & \\
\hline No Icon & ÇALIŞMA ŞARTLARI & 0.21094 & $\longdiv { 0 . 1 1 2 1 8 4 }$ & \\
\hline No Icon & işiN KENDISi & 0.23784 & 0.126491 & \\
\hline No Icon & YÖNETICI & 0.26934 & 0.126097 & \\
\hline No Icon & YAN ODEMELER & 0.23319 & 0.109170 & \\
\hline No Icon & IŞ ARKADAŞLARI & 0.21454 & 0.100438 & \\
\hline No Icon & ILETIŞIM & 0.28293 & $\longdiv { 0 . 1 3 2 4 5 9 }$ & \\
\hline
\end{tabular}

Şekil 5: Superdecisions Kriter Önceliklendirme Sonuçları

\section{SONUÇ VE DEĞERLENDİRME}

Örgütlerin hedeflere ulaşılmasında en önemli bir faktör olan iş tatminin sağlanması ve yükseltilmesi için ilk başta iş tatminini sağlayan faktörlerinin neler olduğunun bilinmesi ve öğrenilmesi gerekir. İş tatminini sağlayan bireylerin; işlerini zamanında yapmaları, devamsızlık yapmadıkları, işten ayrılma ihtimallerinin düşük olduğu, daha az hekime gidip daha az izin aldıkları belirtilmektedir. Dolayısıyla, iş tatminini tamamlanan bireyler işlerin yapımında istekli olacaklardır. Tatminsiz çalışan bireyler işletmelerde, iş aksatma, grev, sendika faaliyetleri, verimsiz çalışma, disiplin gibi sorunlar görülebilmektedir (Erdoğan, 1996, 145).

İş tatmininde yapılacak çalışmalarda esas olan, işletmelerin gelecek planları için pozitif yönde katkı sağlayacak olan iş tatmini kriterlerinin belirlenmesidir. Yapılan bu çalışma ile Kayseri ilinde çalışan tıbbi mümessillerin iş tatmini seviyelerinin ve iş tatminlerini etkileyen kriterlerin belirlenmesi amaçlanmıştır. Spector ölçeğine göre elde edilen ortalamalar incelendiğinde; genel iş tatmini ortalaması 3,06 olarak orta düzeyde elde edilmiştir. Alt kriterlerin ortalaması incelendiğinde ise mevcut durumda en yüksek tatmin olunan kriterin işin kendisi $(3,72)$ olduğu görülmüştür. Diğer kriterlerde tatmin seviyesi ise sirasiyla iletişim $(3,58)$, iş arkadaşları $(3,42)$, yan ödemeler $(3,13)$, yönetici $(3,09)$, ödüllendirmeler $(3,04)$, çalışma şartları $(2,78)$, terfi $(2,54)$, ücret $(2,41)$ olarak karşımıza çıkmıştır. Ancak iş tatmininde bu kriterlerin ikili karşılaştırma ölçeği ile önemlerinin önceliklendirilmesi talep edildiğinde mümessillerin farklı öncelik cevapları verdiği görülmüştür. Analizde ikili karşılaştırmalar sonucunda iş tatminini etkileyen kriterlerin önem sıralaması; iletişim \% 13.24, yönetici \%12.64, işin kendisi \% 12.60, ücret \% 12.26 ve çalışma şartları \%11,21 olarak devam etmektedir. Bu iki ölçeğin sonuçlarının birlikte değerlendirilmesiyle mevcut durumda iş tatmininin en fazla sağlandığı kriter işin kendisi olmasına rağmen, iletişim kriterinin iş tatminini daha fazla etkilediği sonucuna varılabilmektedir.

Gelecekte yapılacak çalışmalarda; yerel düzeyde incelemiş olduğumuz bu analizi farklı illerde uygulayarak karşılaştırmalı sonuçlarının elde edilmesi mümkün olacaktır. Ulusal çapta uygulandığında ise Türkiye'de çalışan tıbbi mümessillerin iş tatmini konusunda daha genel bilgiye ulaşılabilecektir. Bu çalışmada veri toplama anket yöntemiyle uygulanmıştır faydalanılmıştır. Gelecekte yapılacak araştırmalarda anket yönteminin yanı sıra diğer yöntemler (mülakat, gözlem gibi) kullanılarak araştırma sonuçlarının doğruluğu kontrol edilmeli veya mülakat yöntemi gibi yöntemler aracılığıyla elde edilen verilerle sonuçlar daha ayrıntılı bir şekilde yorumlanabilecektir. İş tatminine yönelik literatürde birçok farklı ölçek bulunmaktadır. Bu sebeple araştırmacılar farklı ölçekleri kullanarak benzer nitelikteki çalışmaları uygulama imkanı bulabileceklerdir. Bu çalışmada kriterlerin önceliklendirilmesinde de çok kriterli karar verme yöntemlerinden biri olan AHP'den faydalanılmıştır. Ancak yine literatürde birçok ÇKKV yöntemi bulunmaktadır. Araştırmacılar farklı 
yöntemleri kullanarak belirlemiş oldukları kriterlerin ağırlı̆ıını yöntemler bazında test edebileceklerdir. Çalışma bu açıdan iş tatminine yönelik yapılacak birçok yeni çalışma için ufuk açacaktır.

Tıbbi mümessillerin iş tatmininin artırılması ilaç fïmalarının satış potansiyelleri açısından önemli bir faktör olacağ 1 için, bu çalışma sonucunda elde edilen bulgular, ilaç firmaları tarafindan hassasiyetle incelenmelidir. Oluşan problemler bertaraf edilmeli ve iş tatmininin artırılmasına yönelik çalışmalar firmalar tarfından başlatılmalıdır. Ayrıca bu çalışma tıbbi mümessillere yönelik uygulanmış olsa bile uygulama yönteminin ve şeklinin tüm detaylarıyla çalışma içeriğinde yer almasından dolayı, araştırmacılar farklı sektörlerde çalışan kişilerin iş tatmininin ölçülmesinde ve kriterlerin belirlenmesi bu çalışmayı referans olarak alabileceklerdir. Bu açıdan çalışma araştırmacılar için yol gösterici nitelikte olacaktır. 


\section{KAYNAKÇA}

Akıncı, Zeki, (2002) Turizm Sektöründe İşgören İş Tatminini Etkileyen Faktörler: Beş Yıldızlı Konaklama İşletmelerinde Bir Uygulama, Akdeniz İ̈BF Dergisi, 4, 1-25.

Bakan, İsmail ve Tuba Büyükbeşe, (2004) Örgütsel İletişsim İle İş Tatmini Unsurları Arasındaki İlişkiler: Akademik Örgütler İçin Bir Alan Araştırması, Akdeniz Universitesi Iktisadi ve Idari Bilimler Fakultesi Dergisi, 4(7), 1-30

Başaran, İbrahim Ethem, (1991) Örgütsel Davranış İnsanın Üretim Gücü, Gül Yayınevi, Ankara.

Bender, Keith Allen ve Donohue M ve Heywood, John S., (2005) Job Satisfaction And Gender Segregation, Oxford Economic Papers, 57(3), 479-496.

Bovier, Patrick A. ve Perneger, Thomas V., (2003) Predictors Of Work Satisfaction Among Physicians, European Journal of Public Health, 13(4), 299-305.

Dağdeviren, Metin ve Eraslan, E., ve Kurt, M., ve Dizdar, E. N., (2005) Tedarikçi Seçimi Problemine Analitik Ağ Süreci İle Alternatif Bir Yaklaşım, Teknoloji, 8(2), 115-122.

Davis, K., (1988) İşletmede İnsan Davranış1-Örgütsel Davranış, Çev. Kemal Tosun, İstanbul Üniversitesi İşletme Fakültesi Yayını. İstanbul.

Davis, K., ve Newstorm, John W. (1985) Human Behaviour at Work: Organizational Behaviour, McGraw-Hill.

Davis, K., ve Newstrom, John W., (1989) Human Behavior At Work, McGraw-Hill.

Demir, Nevzat, (2007) Örgüt Kültürü Ve İş Tatmini: Plastik Sektöründe Bir Araştırma, Türkmen Kitabevi.

Deniz, Mehmet, (2005) Bir Tutum Çeşidi Olarak İş Tatmini, Örgütsel Davranış Boyutlarından Seçmeler, 293-337.

Erdoğan, İlhan, (1996) İşletme Yönetiminde Örgütsel Davranış, Avcıol Basım Yayın, İstanbul.

Eren, Erol (2001) Yönetim Ve Organizasyon: Çağdaş Ve Küresel Yaklaşımlar, Management And Organization: A Contemporary And Global Approaches İstanbul, Beta Yayınevi.

Eren, Erol, (2004) Örgütsel Davranış Ve Yönetim Psikolojisi, Beta Basım, İstanbul.

Ergeneli, Azize ve Eryiğit, Mehmet, (2001). Öğretim elemanlarının iş tatmini: Ankara'da devlet ve özel üniversite karşılaştırması. Hacettepe Üniversitesi İI BF Dergisi, 19(2), 159-178.

Eroğlu, Feyzullah, (2010) Davranış Bilimleri, Beta Yayın Dağıtım, 10. B., İstanbul.

Gazioglu, Saziye ve Tansel, Aysit, (2006) Job Satisfaction İn Britain: İndividual And Job Related Factors, Applied Economics, 38(10), 1163-1171.

İncir, Gülten, (1990) Çalışanların iş doyumu üzerine bir inceleme. Milli Prodüktivite Merkezi.

Karahan, Atila, (2009) Demografik Farklılıkların İş Gücü Verimliliğine Etkisi, Selçuk Üniversitesi Sosyal Bilimler Enstitüsü Dergisi, (21), 269-281.

Kavuncubaşı, Şahin, (2000) Hastane Ve Sağlık Kurumları Yönetimi, Ankara, Siyasal Kitabevi, 1. Baskı, Ankara.

Keleş Çelik Hatice Necla, (2006) İş Tatmininin Örgütsel Bağllık Üzerindeki Etkisine İlişkin İlaç Üretim Ve Dağıtım Firmalarında Yapılan Bir Araştırma, Yayınlanmamış Doktora Tezi, Selçuk Üniversitesi Sosyal Bilimler Enstitüsü, Konya.

Keser, Aşkın, (2006) Çalışma Yaşamında Motivasyon, Alfa Aktüel Yayınları, İstanbul.

Korman, Abraham K, Akhun, İlhan ve Alkan Cevat (1978). Endüstriyel ve Organizasyonel Psikoloji. Milli Eğitim Bakanlığı.

Lawler, Edward E., III. (1973) Motivation İn Work Organizations, Monterey, CA: Brooks/Cole

Locke, Edwin A. (1976) The Nature And Causes Of Job Satisfaction, Handbook Of İndustrial And Organizational Psychology, 1, 1297-1343.

Luthans, Fred (1992) Organizational Behaviour, Sixth Edition, New York: McGraw Hill Company.

Metle, Mesh'al Kh, (2001) Education, Job Satisfaction And Gender İ Kuwait, International Journal of Human Resource Management, 12(2), 311-332.

Mohammad Mosadegh Rad, Ali ve Hossein Yarmohammadian, Mohammead, (2006) A Study Of Relationship Between Managers' Leadership Style And Employees' Job Satisfaction, Leadership in Health Services, 19(2), 11-28.

Reitz, H. Joseph, (1987) Behavior İn Organizations, Richard D. Irwin.

Robbins: P., (1996) Organizational Behaviour: Concepts, Applications And Controversies, Prentice-Hall Publishing, New York.

Saaty, Thomas L., (1980) The Analytical Hierarchy Process, Planning, Priority. Resource Allocation, RWS Publications, USA.

Saaty, Thomas L., (1990) How To Make A Decision: The Analytic Hierarchy Process, European Journal Of Operational Research, 48(1), 9-26.

Schultz, Duane P. ve Schultz, Ellen, (1990) Psychology And İndustry Today: An İntroduction To İndustrial And Organizational Psychology, Macmillan Publishing Company.

Smither, R.D., (1998) The Psychology Of Work And Human Performance, Third Edition, New York, Longman

Spector, Paul E., (1997) Job Satisfaction: Application, Assessment, Causes, And Consequences. Vol. 3. Sage publications.

Telman, Nursel ve Ünsal, P., (2004) Çalışan Memnuniyeti, Epsilon Yayınevi, Istanbul.

Temir A., (2002) İnsan Kaynakları Yönetimi, Kara Harp Okulu Basım Evi, Ankara.

Tummala, V. Rao ve Wan, Y. W., (1994) Analytic Hierarchy Process (AHP) İn Practice: A Survey Of Applications And Recent Developments, Journal of Mathematical Modelling and Scientific Computing, 3(1), 1-38. 
Tuta, Y. (2008). Yönetime Katılmada Öneri Sistemleriyle İş Tatmini Arasındaki İlişki Ve Bir Örgütteki Uygulaması, Yayınlanmamış Yüksek Lisans Tezi, Dumlupınar Üniversitesi, Sosyal Bilimler Enstitüsü, İşletme Anabilim Dalı, Kütahya.

Uyargil, Cavide (1988). İş Tatmini ve Bireysel Özellikler. İstanbul Üniversitesi İşletme Fakültesi Yayınları, İstanbul.

Varol, Fatih, Karaer, Memiş, ve Ortakarpuz, Metehan, (2017) İlaç Mümessillerinin Örgütsel Bağlılığının, İş Tatmininin Ve İşten Ayrılma Niyetinin Demografik Faktörler Bağlamında İncelenmesi. Electronic Turkish Studies, 12(31).

Vecchio, Robert P., ve Keon, Thomas L., (1981) Predicting Employee Satisfaction From Congruency Among İndividual Need, Job Design, And System Structure, Journal of Organizational Behavior, 2(4), 283-292.

Yazıcıoğlu, Y., ve Erdoğan, S., (2004) SPSS Applied Scientific Research Methods. Ankara, Detay Publishing.

Yılmaz, Mustafa Kemal, (2006) Stres Ve Motivasyonun, Satış Gücünün İş Tatmini Üzerine Etkisi:Erzurum'daki İlaç Satış Mümessilleri Üzerinde Bir Uygulama, Yayınlanmamış Yüksek Lisans Tezi, Erzurum. 